\title{
Love and justice from a canonical perspective
}

\begin{tabular}{|c|c|}
\hline $\begin{array}{l}\text { Author: } \\
\text { Irimie Marga }{ }^{1,2}\end{array}$ & \\
\hline $\begin{array}{l}\text { Affiliations: } \\
\text { }{ }^{1} \text { Department } \\
\text { Orthodox Facu } \\
\text { University of S } \\
\text { Romania }\end{array}$ & $\begin{array}{l}\text { f Theology, } \\
\text { alty of Divinity, } \\
\text { ibiu, Sibiu, }\end{array}$ \\
\hline $\begin{array}{l}{ }^{2} \text { Department } \\
\text { and Historical } \\
\text { Faculty of The } \\
\text { Religion, Unive } \\
\text { Pretoria, Preto } \\
\text { South Africa }\end{array}$ & $\begin{array}{l}\text { f Systematic } \\
\text { Theology, } \\
\text { ology and } \\
\text { ersity of } \\
\text { oria, }\end{array}$ \\
\hline $\begin{array}{l}\text { Research Proje } \\
\text { Project LeadeI } \\
\text { Project Numb }\end{array}$ & $\begin{array}{l}\text { ct Registration: } \\
\text { r: J. Pillay @ } \\
\text { er: } 04653484\end{array}$ \\
\hline $\begin{array}{l}\text { Description: } \\
\text { The author is } \\
\text { as the researcl } \\
\text { Dean Prof. Dr J } \\
\text { Faculty of The } \\
\text { Religion, Unive } \\
\text { Pretoria }\end{array}$ & $\begin{array}{l}\text { oarticipating } \\
\text { h associate of } \\
\text { Jerry Pillay, } \\
\text { ology and } \\
\text { ersity of }\end{array}$ \\
\hline $\begin{array}{l}\text { Corresponding } \\
\text { Irimie Marga, } \\
\text { irimiemarga@ }\end{array}$ & $\begin{array}{l}\text { g author: } \\
\text { yahoo.de }\end{array}$ \\
\hline $\begin{array}{l}\text { Dates: } \\
\text { Received: } 15 \mathrm{~A} \\
\text { Accepted: } 04 \mathrm{~S} \\
\text { Published: } 29\end{array}$ & $\begin{array}{l}\text { pr. } 2021 \\
\text { Sept. } 2021 \\
\text { Oct. } 2021\end{array}$ \\
\hline $\begin{array}{l}\text { How to cite th } \\
\text { Marga, I., } 202 \\
\text { justice from a } \\
\text { perspective', } \\
\text { Studies/Theolc } \\
77(4), \text { a6748. } \\
\text { org/10.4102/h }\end{array}$ & $\begin{array}{l}\text { is article: } \\
\text { 1, 'Love and } \\
\text { canonical } \\
\text { ITS Teologiese } \\
\text { ggical Studies } \\
\text { https://doi. } \\
\text { its.v77i4.6748 }\end{array}$ \\
\hline $\begin{array}{l}\text { Copyright: } \\
\text { (c) 2021. The A } \\
\text { Licensee: AOS } \\
\text { is licensed und } \\
\text { Creative Comn } \\
\text { Attribution Lic }\end{array}$ & $\begin{array}{l}\text { uthors. } \\
\text { IS. This work } \\
\text { der the } \\
\text { nons } \\
\text { ense. }\end{array}$ \\
\hline Read online: & \\
\hline 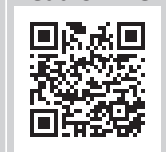 & $\begin{array}{l}\text { Scan this QR } \\
\text { code with your } \\
\text { smart phone or } \\
\text { mobile device } \\
\text { to read online. }\end{array}$ \\
\hline
\end{tabular}

What is the relation between love and justice? In God, love and justice are in perfect harmony. In humans, this harmony depreciates as a result of the sins committed by them. Christ restores harmony between love and justice by tying them to a common element: sacrifice. The Church continues Christ's work and, through all its Mysteries, especially Confession and Liturgy, it searches to raise man to a sacrificial statute, which leads to a harmonisation in love and justice. Apocatastasis and inquisition are the extremes people fell in by the exaggeration of love and justice.

Contribution: Some theologians say that God is more loving than righteous. Others say the opposite. The answer is that in God, love and justice are in absolute harmony. In humans, love and justice are inequitable. Christ restores this lost harmony through a common element: sacrifice. The Day of Judgement will show how much people harmonised love and justice, through Christian sacrifice.

Keywords: love; righteousness; harmony; sin; canon; sacrifice; cross; resurrection; church; mysteries.

\section{Introduction}

The problem of the interconnection between justice and love is one of the most delicate issues of the practical theology, because we find the most sensitive nuancing of the Orthodox spiritual life in it. Many times, we hear that where justice is done, totally or partially, love stops and where there is love, justice cannot be done partially (Buda 2013). From here, the fundamental question arises: how do the two, justice and love, come to harmony? The answer to this interrelation may be given according to the two levels of existence, that is, absolute existence and created existence.

Love and justice have an existential dimension: they spring from God, from the eternal existence, and they situate themselves amongst and in people, who are created for a temporal existence, with the purpose to return from where they started, rounding the enclosure (Boca 2006:3).

\section{Love and justice in God}

Love and justice in God are not in a contradiction, but both have their origin in God. If love and justice are in contradiction, this would mean that God's Being would find himself at contradiction, which is preposterous. For God, love means to be righteous; and justice means manifesting his love.

Harmony is the fundamental feature of divine existence and of trinitarian inter-personal communion. All God's actions, especially what he 'wants' and what he 'can do' are in complete harmony, an expression of God's all-powerfulness. All God wants, he can do but from all he can do, he chooses, in harmony, what he wants. In him, there is no contradiction, namely, his actions do not impede one another, they cannot contradict themselves, the way this happens at the level of fallen humanity.

God's justice springs out of love, it is not a lawful justice, but a merciful justice, which forgives and helps. In this respect, Rev. Stăniloae (1978) wrote:

God is not righteous without being merciful and is not merciful without being righteous [...]. Had God been only righteous, He would not be fully free; had He been only merciful, He would not mind the human efforts and would not encourage them. (p. 248)

In turn, God's love cannot be selfish or interested, because this would mean that his love would not be righteous.

Note: Special Collection: Lucian Blaga University, Sibiu, Romania, sub-edited by Daniel Buda (Lucian Blaga University) and Jerry Pillay (University of Pretoria). 


\section{Love and justice in human beings}

In the act of his creation, God manifested his righteous love. The entire cosmos was created out of divine love, the fundamental reason of creation. A commandment in Heaven, as a call to a superior existence. Sadly, man did not listen and thus, his fall led to the weakening of the tie between love and human justice.

The love of the fallen human was not interested any more in trinitarian love. From the love and uprightness from the act of creation, man got to an interested love and formal fairness that were not in harmony any more. This is and will always be the result of $\sin$ as separation from God (Rahner 1966:439-459).

Man's fall into sin not only led to a depreciation of original harmony, but also to a perversion in the relationship between man and nature. The commandment in heaven, unique and unrepeatable, was a call from God to man to achieve perfection through obedience, a call to overcome simple, natural existence by rising to a superior existence through love and spiritual communion with God in justice and truth. Unfortunately, man did not reply to this call positively.

Men fell. Therefore, a disharmony was created between man and nature; a fact expressed through his banishment from heaven, through the hostility of 'thorns and thistle', an unpleasant fact which can only be overcome by 'the sweat of your face' (Gn 3:18-19). This resulted in suffering, pain and especially death, ${ }^{1}$ as maximum separation from nature and God.

Man cannot come to peace with death but sees in it his greatest enemy. From the suffering brought about by his fall and death, springs the man's strive towards salvation. This degenerated nature of man results into the birth of the natural right, as an aspiration for the better, for the restoration of primordial harmony.

But by living only at the level of nature, man cannot reach happiness, in communion with God, because by his own power he cannot defeat death. Man must seek beyond, for other laws, for something else or someone else, who could raise him to an existencefree from the shackles of the fear of the death? , to a better and happier existence in which love and justice find their harmony.

In this natural unhappy existence, threatened by death, man needs to take measures to make his life better.

1.Death is a non-sense; it is the opposite of the divine creative act. Next to the fact that it brings man to an end, death also brings much suffering and throws life into great absurdness. In essence, death does not belong to man's created nature, but it great absurdness. In essence, death does not belong to man's created nature, but it destructs nature, and this destruction is so tight that it leaves the impression that death itself is a law of nature, or that it is natural. Death is not natural; it is the contrary of nature and life. Here one may discover the fundamental and unmistakable difference between Christian thinking and the materialistic one; while the Christian sees death like a non-sense, the materialist perceives death as a natural law, he comes to peace with it, and he even finds a sense and necessity in death
By this, man proved that he is the only being who creates laws, ${ }^{2}$ with the purpose of raising his existence to a more just status. Only man can make his own laws and, freely, submit to them (Stan 1943). No other being is able to do so.

This, in principle, led to the creation of positive law, that has gone through a complex evolution. The progress of humanity in civilisation was determined undoubtedly by the progress made in legislation; the more evolved the society, the more complex the system of laws governing it. The Roman Empire was the one which raised man's act of creating laws to a very high level, as also thinking and judicial sciences which influenced afterwards the entire mankind, up to the present. The evolution of positive law will only be concluded when the world ends.

However, no matter how complex the judicial system of a society is, it cannot ensure man's happiness, that is, it cannot make man to love righteously and to dispense merciful justice. It is true that a civilised society, based on the rule of law, cannot permeate the human soul, which is marked by sin. Positive law has man as the author and not God from whom salvation comes.

In his creative act of laws, man unfortunately could not overcome his sinful condition. Furthermore, his sinful corrupted state has been influencing the laws he has been making. The logics of the positive law and the judicial laws have progressively been alienated from the logics of the Christian perfection. We could say that, in essence, the greatest weakness of the positive law was and remains to be human selfishness and judicial formalism (Del Vecchio 1993; Djuvara 1941; Speranția 1946).

Personal selfishness as well as the collective selfishness of those who are in power, has swathed all forms of subjective interest, continuously determining the legal act with a view to perpetuating their personal power, ignoring or, even worse, destroying all the other values.

This fact was also noted by the Roman law-writers when they said: 'auctoritas, non veritas, facit legem' ('authority, not truth, makes the law'). In law-writing, all that matters is power and the majority and not necessarily a hierarchy of values, nor the harmony between love and justice, that is why the Romans created another judicial saying: 'error communis facit jus' ('common error gives birth to law') (Sherwin-White 1978).

Therefore, positive law cannot save man, the idea of creating a perfect judicial system that would save man or make him

2.Scholastics described God's image in man in three aspects, reason, will and feeling, which, to a greater orsmaller extent, we may also find in animals. The Holy Fathers, nevertheless, described God's image in man by other aspects, more clearly and unequivocally: man is the only being capable to have a religious feeling (homo unequivocally: man is the only being capable to have a religious feeling (homo religious, as stated by Mircea Eliade), the only being who is capable to communicate by word of mouth and the only being capable to create laws. These three aspects best characterise the man's soul and exclude any confusion in relation to othe created beings, emphasising the dichotomic constitution that only man has. The other beings, created without soul, cannot ever overcome the natural status of instinct. On the contrary, man, by his capacity to create laws, has the possibility to overcome instinct and all the other laws that may determine it. 
happy is a utopian fantasy. Christ did not want to do away with laws and the political regime that was governing at the time because he knew that, by doing this he cannot bring salvation to people.

From this captivity of death and selfishness, man was not able to ascend alone, that is why he needed God's intervention. Only God, from his endless love, had the initiative of salvation, enlightening the man to a holy law, a law superior to the positive law made by man. Only this way, the law, as an expression of divine justice, has received a spiritual and vertical dimension and man wrote it in his heart through love. When man obeys the holy law (the 10 commandments revealed to Moses on Mount Sinai), man actually obeys God.

Moses' law, of the Old Testament, had a prophetic character because it prepared Messiah's path. In the old law, man discovered the superior sense of existence, in obedience to God, and the necessity of revelation ('to have no other gods besides me') (Schwarz 1997).

By the commandment that forbade murder and the one of making likeness (false gods), the old law raised man from the threat of death and from the temptation of making idols out of matter. Through all these, the helplessness threatening the harmony between love and justice was overcome, even if not removed entirely.

The old law ascended man to a vertical existence, as in fact is his stature, but still, the old law did not save man, did not bring him full happiness, did not open heaven to him. Why? Because this law did not overcome sin in its essence, namely the ancestral sin, sin was only forbidden but not purified, sin was removed but not cleansed. The Jews felt and wished to purify themselves from sin, and that is why they would sacrifice in the old Temple, only that the spilled blood of the animal could not lead to the forgiveness of the ancestral sin. The fundamental idea of the Old Testament was the need for Messiah, the need for the Saviour, who should really redeem the world from sin.

Had the old law purified mankind from sin, there would have been no need for Christ's coming. Thus, original sin, as separation from God, had remained the greatest impotence of the old law which opened the road to the New Covenant. The old law was only a 'tutor to bring us to Christ' (Gl 3:24).

Divine providence tried through the old law, given to Moses, to raise man from this decayed status. Love and justice have become superior, but their harmonisation by the old law was not possible because this law did not overcome sin in essence.

As long as the sin remained in the world, love and justice, in inter-human relationships, were threatened with the separation from their absolute spring.

\section{The restoration of harmony between love and justice through salvation}

The New Covenant is the law brought by Christ; and the parasite of nature, death, is defeated by resurrection. Selfishness, as a weakness of law made by man, is defeated by absolute love.

Christ indeed fulfilled the sense of law in the iconomy of salvation, namely, through the New Covenant - man is ontologically transformed, he regains the communion with God, the eternal life and thus, with happiness. Not only man gains the dignity for which he was created but the law in itself is absolute, raised from the statute of enemy to the statute of friend and in service for man, as the psalmist would prophesise: 'But his will is in the law of the Lord, and in His law, he meditates day and night' (Ps 1:2).

The New Covenant requires inner transformation, repentance, as a characteristic of everything Christ brought, an authentic love united with a saving justice, far away from any form of legalism or formalism. Legalism and formalism mean obeying the law without conviction, only in form, and without love.

The New Covenant calls us to fulfil it through obeyance and not by force, through convincing and not by constraint. We do not find ourselves in any terminological confusion here but in the truthful revelation of the sense of law.

The New Covenant also means a redefining of the concept of 'law' (Moldovan 2015), which receives maximum value in the work of salvation (Panmolle 1973). The New Covenant restores the relation between love and justice, it does not impose anything on us, on the contrary, it frees us from any constraint, as free personal beings, when we thirst for justice and when we truly love.

On the one hand, Christ wants to raise love from its selfish fall, and the raise is a maximum one, up to the Sacrifice on the Cross: 'For God so loved the world that He gave His only begotten Son, that whoever believes in Him should not perish, but have everlasting life' (Jn 3:16). If in the Old Testament the love towards one's neighbour had as a model love of self, in the New Covenant, the Saviour brings supreme love, sacrifice, he being the model himself.

On the other hand, Christ wants to restore justice from its formalist fall, and its restoration goes up to assuming the righteous plan to save the world, namely, up to the Sacrifice on the Cross. This is the sense of the words addressed to Saint John the Baptizer, when he says to him: 'Permit it to be so, for thus it is fitting for us to fulfill all justice' (Mt 3:15). Christ's justice is not the justice of the world any more, but the justice of the Kingdom of God based on his Sacrifice. Christ urges towards this justice: 'But seek first the Kingdom of God and His justice, and all these things shall be added to you' (Mt 6:33) (Nolland 2005). 
In this way, through the New Covenant, love and justice harmonised again, because Christ raised them to their common element: sacrifice. The way the Sacrifice on the Cross leads to Resurrection, the same way the sacrificial love and justice leads to harmony and happiness.

Nevertheless, until he gets to the Cross, the restauration of the relation between love and justice may be found in the entire activity of the Saviour. For example, when human justice wants the death of the adulterous woman, Christ answers with divine justice, and asks that only he who is without sin should throw the stone at her (Jn 8:7). Similarly, when man's selfish love asks to love one's parents more than God, Christ would answer with sacrificial love: '... let the dead bury their own dead' (Mt 8:22).

In the parable of the vineyard workers (Mt 20:1-16), according to the fallen human justice, the reward should have come by the quantity of the work performed, namely, according to rules that mind time and space, in an imperfect natural order. However, the reward of the vineyard landowner comes according to intentions, quality of work, sacrifice, namely, according to the rules that overcome time and space in the soteriological order of existence. Therefore, this parable, from the human outlook, seems unjust, but from the perspective of salvation, it is a correct parable 'Friend, I am doing you no wrong' (Mt 20:13). Behold how much love there is in the justice that rewards the last the same as the first!

When love and justice are raised to the quality of sacrifice, then the harmony between them comes from itself. Without suffering, love and justice remain fallen and lost, separated from salvation. Hence, one may say that love and justice harmonise only through Christ's Sacrifice and Resurrection. The centre of absolute harmony is constituted by the Cross. Through the Cross, Christ shows us that justice may be loving and that love may be right. Without sacrifice, love breaks away from justice and falls into sentimentalism and vice versa, justice breaks away from love and falls into formalism. Christ is the One Who illuminated to us that justice is founded on love and love perfects through justice.

Another example of injustice through sin found in Scriptures is where we are told that parents' sins fall onto their descendants, onto their children (Ex 20:5). After all, everyone suffers from the consequences of the ancestral sin and hence the question is born: is it right that descendants suffer because of their ancestors? Where is justice? How can we explain the injustice of the fact that parents' sins fall onto children?

The answer is this: the falling of sin unto children is the consequence of the injustice done through sin. Injustice cannot have righteous consequences. It would mean that injustice would be perpetuated. Some blame God for the perpetuation of the injustice of sin onto descendants when, in fact, this injustice is the consequence of unjust sin and lack of love that it goes with.
This is in parity to a disease, which, the uglier, the more transmittable. Disease transmissibility does not happen because of the ill person but because the disease is malevolent and unjust. Therefore, man's fate is to beware of the disease, namely the sin, the injustice of the ill transmitting the disease to the healthy.

Man must always be scandalised by this sin-transmitting to innocent descendants, a fact that should motivate them to run away from it. Salvation means: our liberation from the scandal of transmitting sins of parents onto their descendants.

The One Who scandalised the most from this injustice was God himself. Therefore, the salvation initiative was also started by him. This was the message of the Protoevangelium which lay at the foundation of waiting for the Messiah.

Christ-Messiah's fate was that through his Sacrifice and his Resurrection, he would raise us beyond this injustice of sintransmitting from parents to descendants. That is why our salvation starts when we are reborn through Baptism, which breaks away the transmitting of the ancestral sin by erasing it and opens the road to salvation. In this way, man ascends from the injustice and lack of love in the world of sin to Christ's holy justice and his endless love.

Restoration of harmony between love and justice, the way Christ wants, is suggested by the words: 'A new commandment (justice) I give to you, that you love one another as I loved you' (Jn 13:34).

\section{Love and justice in the historic reality of the church}

The Church finds itself in a theandric reality and has the role to advance human realities to the divine realities, but also to descend the divine realities amongst the humans and thus achieve salvation. Love and justice in social-human realities are in continuous conflict. The Church has the role to advance the relation between love and justice from a social level to Christ, namely from conflict to harmony.

This is a mysterious work and cannot be done without suffering. All Church mysteries pursue this purpose, but most evidently, this harmony is to be achieved in the mystery of Confession. Narrow-minded love and selfish justice of men meet, in this mystery, with God's merciful love and absolute justice (Phidas 1998; Potz \& Synek 2014).

Through Confession, the sin as a product of injustice and lack of love (or selfish love), looks for healing in God's love and justice. The sin cannot receive healing through human fairness or human justice. That is why there is a need to keep the secret of Confession, so that a person's sins would not be known and judged by others, in a formalist and legalist logic, but judged and made right in God's sacrificial love and endless justice. 
The priest aims not to submit the faithful to civil laws or to penal judgement, but to save them from the slavery of sin, from the lack of freedom, injustice and insufficiency through love selfishness. This is the meaning of ecclesial cannons, born out of saving justice and sacred love (Stan 2010-2019). The priest that breaks the secret of Confession separates himself from the true Christian mission, therefore, the Church canons punish him with the maximum punishment of defrocking (Milaș 1930-1936).

However, the full harmony of justice and love will happen only on the Day of Judgement. Then divine justice will be made by love and love will become absolute through justice for eternity. On the Judgement Day, justice through love will be absolute, namely, deep and lasting, and love through justice will be good, according to the model of the world Judge.

Here is why the Judgement Day is not like justice or human trials, but it is the moment in which each man is discovered according to how much he blended love and justice in his life, namely, how much he reached holiness.

Throughout history, the lack of balance between love and justice has led to many exaggerations. For example, the exaggeration of love, unfavourable to justice has led to the heresy of apocatastasis, condemned by the Church. Through apocatastasis, God's endless love was exaggerated, in that it gets to forgiving all sins and thus suppresses hades, neglecting the fact that God is also right, and each of us must endure the consequences of our acts.

On the other hand, the exaggeration of justice, unfavourable to love has led to religious horrors, such as inquisition, crusades, religious wars, etc., through which unforgiving justice was searched by fire and sword. Christ's message however, is that there is no pure love without justice, nor holy justice without love.

Being a Christian is, therefore, meant that, in his life, he harmonises love and justice through sacrifice, and this harmonising is not an easy, but it keeps us in an edifying tension for the Kingdom of God. All our deeds, everything that happens around us, must be seen in the perspective of love and sacrificial justice. When the ability to sacrifice oneself disappears, one of the two is neglected, either love or justice, and one may get to fall (L'Huillier 1964).

The analysis of the way in which man may relate to a common case may lead to a better understanding of his call to a harmonisation between love and justice through sacrifice. In this sense, we may take the simple case of a child who, playing with a ball, breaks a window and evaluate love and justice. The presence of love or justice will be written down with the value number 1 , respectively their absence with value number 0 . The result is given in Table 1 , where there may appear situations from relating oneself to this case.
TABLE 1: The presence of love or justice.

\begin{tabular}{lccl}
\hline The case & Love & Justice & The situation \\
\hline 1. A child breaks a window & 0 & 0 & Indifference \\
2. My own child breaks a window & 1 & 0 & Selfishness \\
3. A child breaks my window & 0 & 1 & Legalism \\
4. My own child breaks my window & 1 & 1 & Sacrifice \\
\hline
\end{tabular}

As seen in Table 1, there practically may exist four scenarios according to how the deed is assumed, and the resulted situations are: indifference, selfishness, legalism, sacrifice. The first three suffer either because of lack of love or lack of justice. The only scenario that harmonises love and justice is through sacrifice.

The conclusion is that man gets to fulfill Christ's call only in a state of sacrifice, only when he is able to raise personal existence from sin to harmony and eternal bliss. We should understand Christ's words as follows: 'Whoever desires to come after Me, let him deny himself, and take up his cross and follow $\mathrm{Me}^{\prime}$ (Mk 8:34).

Christ, the Son of God, is the One that relates to us in a state of continuous Sacrifice. Therefore, the Liturgy, the Eucharist offering, is the centre of our existence, and only the Liturgy keeps the world alive. This state of sacrifice must also include us if we want to be saved. Formalist Orthodoxy, reduced only to praising and empty words becomes heavier than the heresy. The Church canons require transposing Orthodoxy in righteous deeds, accomplished with love, through a dignified bearing of the Cross, leading to Resurrection and absolute happiness. Love and justice harmonise themselves by fully assuming Christ's work and teaching, transposing them into the most common elements of our lives.

Suggestively, the fulfilling of this harmony may be expressed through the words: Do you love? Be righteous! Do you want to be righteous? Love!

\section{Acknowledgements Competing interests}

The author declares that he has no financial or personal relationships that may have inappropriately influenced him in writing this article.

\section{Author's contributions}

I.M. is the sole author of this article.

\section{Ethical considerations}

This article followed all ethical standards for research without direct contact with human or animal subjects.

\section{Funding information}

This research received no specific grant from any funding agency in the public, commercial or not-for-profit sectors. 


\section{Data availability}

Data sharing is not applicable to this article as no new data were created or analysed in this study.

\section{Disclaimer}

The views and opinions expressed in this article are those of the author and do not necessarily reflect the official policy or position of any affiliated agency of the author.

\section{References}

Boca, A., 2006, Cărarea Împărăției, Editura Episcopiei Aradului, Deva.

Buda, D., 2013, 'God of Life lead us to justice nd peace: An Orthodox Interpretation of the 10th World Council of Churches (WCC) assembly theme from biblical perspective', Teologia 54(1), 11-20.

Del Vecchio, G., 1993, Lecții de filosofie juridică, Editura Europa Nova, București.

Djuvara, M., 1941, Precis de filosofie juridică, Tipografia ziarului Universul, București.
L'Huillier, P., 1964, 'L'Esprit du droit canonique orthodox', in Mesager de I'Exarchat du Patriarcat Russe en Europe Occidentale, pp. 46-47, 108-119, Edition Sainte-Geneviève, Paris.

Milaș, N., 1930-1936, Canoanele Bisericii Ortodoxe însoțite de comentarii, 4 bd, Editura Episcopiei Aradului, Arad.

Moldovan, S., 2015, 'Imperativul (normă, lege, poruncă, ordine, rânduială, disciplină, autoritate): O perspectivă onto-teologică', Revista Teologică 2, 123-131.

Nolland, J., 2005, The Gospel of Mathew, Eerdmans, Grand Rapids, MI.

Panmolle, S.A., 1973, II dono della Legge e la Grazia della Verita, Ave, Rome.

Phidas, V., 1998, Droit canon, Geneve (2008, Editura Trinitas, lași), Chambesy.

Potz, R. \& Synek, E., 2014, Orthodoxes Kirchenrecht, Verlag Plöchl, Freistadt.

Rahner, K., 1966, 'The commandment of love in relation to other commandments', Theological Investigations, b.5, Helicon Press.

Schwarz, B.J., 1997, 'What really happened at Mount Sinai? Four biblical answers to one question', Bible Review 13(5), 20-46.

Sherwin-White, A.N 1978, Roman society and Roman law in the New Testament, Baker, Grand Rapids, MI.

Speranția, E., 1946, Introducere în filosofia dreptului, Tipografia Cluj, Cluj.

Stăniloae, D., 1978, Teologia Dogmatică Ortodoxă, 3 bd, Editura Institutului Biblic și de Misiune al Bisericii Ortodoxe Române, București.

Stan, L., 1943, Ontologia iuris, Editura Arhiepiscopiei Sibiului, Sibiu.

Stan, L., 2010-2019, Biserica și Dreptul. Studii de Drept Canonic Ortodox, 10 bd, Editura Andreiana, Sibiu. 